\title{
Analysis on the Innovative Ways of Employment and Entrepreneurship Guidance in Higher Vocational Colleges Under the Education of "Three All-round Education"
}

\author{
Linman Zhang \\ HENAN TECHNICAL INSTITUTE, Zhengzhou 450042, Henan, China.
}

Abstract: The educational concept of "Three All-round Education" emphasizes all-staff education, full-process education, and all-round education. At present, this education concept has been applied in many courses and is a new era curriculum, one of the important ideological guidelines for teaching reform. As far as the employment and entrepreneurship guidance work and teaching in higher vocational colleges are concerned, this is an important guiding course for solving the employment and entrepreneurship problems of higher vocational graduates in the new era. The quality of course teaching must be ensured and guided by the concept of "three comprehensive education". It is of great significance for curriculum innovation and development. This article introduces the basic connotation of the "Three Comprehensive Education", analyzes the necessity of the application of the "Three Comprehensive Education" concept in the employment and entrepreneurship guidance work of higher vocational colleges, and explores the actual situation of the employment and entrepreneurship guidance work in the higher vocational colleges. This is the innovation path of employment and entrepreneurship guidance work in higher vocational colleges under the education of "Three All-round Education".

Keywords: "Three All-round Education"; Higher Vocational Colleges; Employment and Entrepreneurship; Guidance Work; Innovation

\section{Overview of "Three All-round Education"}

\subsection{The connotation of "Three All-round Education"}

The concept of "Three All-round Education" was first put forward in the 1980s. This teaching concept has been developed to this day and has experienced a long development process. In the subsequent important speeches and work conferences of national leaders on education, they emphasized the concept of three-dimensional education. The 19th National Congress of the Communist Party of China also pointed out that the new era should speed up the concept of three-dimensional education in ideological and political education. From the perspective of the basic connotation of "Three All-round Education", "Three All-round" refers to all-staff education, all-process education and all-round education. This teaching concept emphasizes the importance of full participation in teaching, the whole process through and the all-round development of talents. Applying this teaching concept to the employment and entrepreneurship guidance of colleges and universities is important for the development of curriculum teaching and the promotion of comprehensive talents. Significance is an important part of the current advanced educational concepts.

\subsection{The necessity of applying the concept of "Three All-round Education" in the employment and entrepreneurship guidance of higher vocational colleges}

\subsubsection{Inevitable requirements for improving the pertinence of employment and entrepreneurship guidance}

The "Three All-round Education" concept emphasizes all-staff education, all-process education, and all-round education. Simply put, in the training of students in higher vocational colleges, all employees participate and coordinate education; the

Copyright $(2020$ Linman Zhang

doi: 10.18686/ahe.v4i10.2942

This is an open-access article distributed under the terms of the Creative Commons Attribution Non-Commercial License (http://creativecommons. org/licenses/by-nc/4.0/), which permits unrestricted non-commercial use, distribution, and reproduction in any medium, provided the original work is properly cited. 
goal of talent training is throughout.; Cultivate more comprehensive skill application talents, which is also consistent with the current talent training goals of higher vocational colleges. Therefore, in the employment and entrepreneurship guidance work of higher vocational colleges, in-depth development and application of the concept of "three comprehensive education", Can better guide the employment and entrepreneurship guidance of the school, promote the improvement of the quality of the whole physical education, provide more targeted employment and entrepreneurship guidance for students, and promote the continuous improvement of the employment and entrepreneurship competitiveness of vocational graduates.

1.2.2 Inevitable requirements to promote the innovative development of employment and entrepreneurship guidance in higher vocational education

In the employment and entrepreneurship guidance work of higher vocational colleges, the introduction of the concept of "three comprehensive education" can effectively guide the development of curriculum teaching and promote the reform, development and innovation of employment and entrepreneurship in higher vocational colleges. Advanced education based on the "three comprehensive education" Ideas and effective method guidance can provide scientific guidance for employment and entrepreneurship guidance, promote the innovative development of employment and entrepreneurship guidance, and make up for the problems and deficiencies in traditional employment and entrepreneurship guidance.

\section{Current situation of employment and entrepreneurship guidance in higher vocational colleges}

From the current situation of employment and entrepreneurship guidance in higher vocational colleges, there are still many problems, mainly in the following aspects.

\subsection{Lack of a comprehensive curriculum system, lack of full participation in employment and entrepreneurship guidance}

At present, in many higher vocational colleges, the development of employment and entrepreneurship guidance has not yet formed a all-round curriculum teaching system, but is only carried out as a public curriculum. There are relatively few related class hours and no strict and standardized curriculum assessment mechanism. As for other professional courses, the degree of attention paid to employment and entrepreneurship guidance is seriously insufficient, and relevant guidance is carried out more randomly, and the overall teaching quality cannot be guaranteed.

In addition, in the employment and entrepreneurship guidance work, the relevant teaching personnel are relatively good, only employment and entrepreneurship guidance teachers, and other professional teachers and subject teachers lack guidance on employment and entrepreneurship.

\subsection{Course teachers are not very professional, which affects the effect of guidance}

In the employment and entrepreneurship guidance of higher vocational colleges, the current overall employment and entrepreneurship teachers' guidance is not very professional. Many career and entrepreneurship guidance courses in higher vocational colleges have only been newly added in recent years, so there are serious problems in the construction of the teaching team. Lead to the lack of experience of relevant teachers in the development of employment and entrepreneurship guidance teaching work, and lack of practice in employment and entrepreneurship. Therefore, it is difficult to guarantee the quality of employment and entrepreneurship guidance.

\subsection{Ignore the guidance of all-round education and lack of student competitiveness}

In the current employment and entrepreneurship guidance work carried out by vocational colleges, there is no reliable educational support. The employment and entrepreneurship guidance is largely a mere formality and it is difficult to guarantee practicality. In the specific employment and entrepreneurship guidance, there is no omni-directional and full-process education concept. It only takes employment and entrepreneurship guidance as a course for graduating students. Moreover, in the actual development of the curriculum, there is a phenomenon that teaching is just a formality. To achieve the ideal effect of educating people, the graduates' employment and entrepreneurial competitiveness has not significantly improved after receiving employment and entrepreneurship guidance.

\section{Effective countermeasures for the innovation of employment and entrepreneurship guidance work in higher vocational colleges under the background of "three all- round education"}

\subsection{Improve the construction of the curriculum system and promote the participation of all employees}

In the new era, to carry out employment and entrepreneurship guidance work in higher vocational colleges, we must 
first improve the employment innovation guidance curriculum system, and make employment and entrepreneurship guidance courses one of the compulsory courses for students in higher vocational colleges. The system is perfect, the course content is rich, and the practicality of course teaching is improved.

In addition, in the employment and entrepreneurship guidance, to achieve full participation, all vocational college course teachers are required to regard students' employment and entrepreneurship as one of the basic teaching goals of course teaching. In the course teaching, employment and entrepreneurship guidance should be penetrated for the future of students. Lay a solid foundation for employment and entrepreneurship, strengthen learning accumulation, and enhance the employment competitiveness of future graduates of higher vocational colleges.

\subsection{Enhance teachers' professionalism and carry out teacher training}

Under the concept of "three-round education", higher vocational colleges should further enhance the strength of employment and entrepreneurship teachers, improve the employment and entrepreneurship guidance system, strengthen the construction of innovation and entrepreneurship platforms, change the way teachers teach and improve the ability of employment and entrepreneurship guidance, so as to create a high-level faculty team promotes the high-quality development of employment and entrepreneurship. In this regard, higher vocational colleges should actively organize employment and entrepreneurship teacher training. The training courses cover basic theories of career planning and career planning consultation, career assessment and career ability assessment models, job search strategies, frontier concepts of university employment development, and career guidance curriculum framework And the teaching mode, the transformation operation mode of scientific and technological achievements of colleges and universities in the new era, how college teachers can solve the pain points and difficulties in students' entrepreneurship, innovative thinking training and entrepreneurial cognitive exchanges, innovation and entrepreneurship competition guidance, etc. Through training, teachers will further broaden their horizons, increase their knowledge, update the concepts of employment and entrepreneurship education, and accumulate employment and entrepreneurship knowledge, so as to provide strong talent support for better innovation and entrepreneurship education and teaching in the future.

\subsection{Carry out all-round education and promote breakthroughs in employment and entrepreneurship guidance}

In the employment and entrepreneurship guidance of higher vocational colleges, the school should take the concept of three-dimensional education as the guide, build a comprehensive education system, and ensure the actual effect of curriculum development. It is necessary to further improve the construction of the curriculum security system, increase the importance of curriculum teaching, promote employment and entrepreneurship work to achieve better results, and truly play a positive role in guiding the employment and entrepreneurship of vocational students.

Conclusion: At this stage, the problem of employment difficulties for college students has developed into a social problem. In the incentive job competition, graduates of higher vocational colleges face greater employment pressure. In this regard, relevant higher vocational colleges have begun to guide employment and entrepreneurship Work is one of the daily teaching tasks to improve students' employment and entrepreneurship ability. However, there are still some outstanding problems in the employment and entrepreneurship guidance work of higher vocational colleges. For this, it is necessary to further innovating educational concepts. The concept of full education is to promote the innovation and development of employment and entrepreneurship guidance.

\section{References}

1. Cheng S. Research on the practice of employment and entrepreneurship guidance service for college students based on "three all-round education"___ Taking Ningxia University as an example. Think Tank Times 2020; (11): 158-159.

2. Zhu P. The role and positioning of counselors in the "three-dimensional education" in colleges and universities-Also on the characteristics and functions of "education". Ideological and Theoretical Education 2020; (03): 86-91.

3. Cai W, Han L. The exploration of the refined employment guidance work system for college students under the concept of "three all-round education"___ Taking the school of Mechanical and Electrical Engineering of Jiangxi University of Science and Technology as an example. Southern Agricultural Machinery 2020; 51(03): 177-179.

4. Peng Y, Zhang Z. A practical research on the employment guidance service system for college students based on the theory of "three holistic education"_—_ Taking the school of Foreign Languages of Hunan Agricultural University as an example. Guangxi Quality Supervision Guide 2019; (11): 23-24.

5. Guo M. "Four-in-one" employment guidance work model for secondary colleges in colleges and universities under the context of "three all-round education"—_-Taking L colleges and W colleges as an example. China College Student Employment 2019; (18): 55-59. 